\title{
DETERMINATION OF MERCURY ANOMALY ZONE USING ORDINARY KRIGING METHOD IN PAMANCALAN GEOTHERMAL FIELD
}

\author{
Alfaridzi Meifano ${ }^{1, a)}$, Bondan Novanis Punto Aji ${ }^{1, b)}$ \\ ${ }^{1}$ Teknik Geologi, Fakultas IImu dan Teknologi Kebumian, Institut Teknologi Bandung \\ e-mail : a)alfaridzi.meifano@students.itb.ac.id, b) bondannovanis@students.itb.ac.id
}

\begin{abstract}
Abstrak. Daerah panas bumi Pamancalan memiliki potensi untuk pengembangan bidang panas bumi dengan implikasi mata air panas sebagai manifestasi permukaan panas bumi dan posisi daerah Pamancalan dalam tatanan tektoniknya termasuk dalam jalur magmatik Jawa bagian selatan dengan lingkungan vulkanik. Penelitian tentang persebaran nilai $\mathrm{Hg}$ di daerah Pamancalan sebelumnya telah diestimasi oleh Pusat Sumber Daya Geologi (PSDG) Jawa Barat. Akan tetapi, tidak dicantumkan metode yang digunakan dalam estimasi tersebut. Hal ini menyebabkan tidak diketahui nilai error yang ada pada metode estimasi tersebut. Oleh karena itu penulis memutuskan untuk melakukan estimasi persebaran dari unsur $\mathrm{Hg}$ di lapangan panas bumi Pamancalan dengan menggunakan metode ordinary kriging. Tujuan dari penelitian ini adalah untuk mengestimasi nilai merkuri $(\mathrm{Hg})$ dan menentukan zona anomali $\mathrm{Hg}$ menggunakan metode ordinary kriging. Analisis dilakukan dengan menggunakan data $\mathrm{Hg}$ yang diperoleh dari laporan panas bumi Pamancalan yang dibuat oleh Pusat Sumber Daya Geologi, Badan Geologi, Kementrian ESDM RI. Penelitian ini dilakukan pada 136 data $\mathrm{Hg}$ yang dianalisis menggunakan Exploratory Data Analysis (EDA), Exploratory Spatial Data Analysis (ESDA), semivariogram, dan ordinary kriging. EDA dan ESDA dilakukan secara bersamaan sebelum dilanjutkan ke semivariogram dan kriging. EDA dilakukan untuk mengetahui karakterisitik data $\mathrm{Hg}$. Hasil EDA menunjukkan bahwa data awal $\mathrm{Hg}$ tidak terdistribusi normal dan tidak stasioner serta terdapat banyak outlier sehingga dilakukan transformasi logaritma pada data awal. Setelah ditransformasi, data menunjukkan distribusi yang relatif normal dan stasioner. ESDA bertujuan untuk menentukan hubungan dan distribusi spasial dari nilai $\mathrm{Hg}$ dan menentukan treatment terhadap outlier. Hasil ESDA menunjukkan bahwa sampel diambil secara acak dan terdiri dari satu populasi. Sebelum dilakukan estimasi dengan ordinary kriging, semivariogram dibuat untuk menentukan jarak maksimum data yang masih berhubungan secara spasial. Pembuatan semivariogram dilakukan dengan beberapa percobaan sehingga diperoleh model semivariogram yang paling ideal. Estimasi oleh ordinary kriging menunjukkan bahwa zona anomali $\mathrm{Hg}$ berasosiasi dengan sesar yang berorientasi NW-SE di barat dan timur dan di selatan yang berorientasi NE-SW. Hasil estimasi Hg (Log ppb) berkisar antara 1,869-1,989.
\end{abstract}

Kata Kunci: Hg; zona anomali; ordinary kriging; Pamancalan

\begin{abstract}
Pamancalan geothermal region has a potential for the geothermal field development by implicating hot springs as the geothermal surface manifestation and the position of Pamancalan region in its tectonic setting including the southern Javanese magmatic pathway with the volcanic environment. Research on the distribution of $\mathrm{Hg}$ values in the Pamancalan area had previously been estimated by the Pusat Sumber Daya Geologi (PSDG). However, there is no information about method that used for the estimation. This causes the unknown error value in the estimation method. Therefore, the authors decided to estimate the distribution of $\mathrm{Hg}$ elements in the Pamancalan geothermal field by using the ordinary kriging method. The purpose of this paper is to estimate the value of mercury $(\mathrm{Hg})$ and determine the anomaly zone of mercury using the ordinary kriging method. The analysis was conducted by using mercury data obtained from the Pamancalan geothermal report that made by Pusat Sumber Daya Geologi, Badan Geologi, Kementrian ESDM RI. This research was conducted on 136 mercury data that was analyzed using Exploratory Data Analysis (EDA), Exploratory Spatial Data Analysis (ESDA), semivariogram, and ordinary kriging. EDA and ESDA are carried out together before being continued to semivariogram and kriging. EDA was conducted to study the characteristics of mercury data. The results of the EDA show that the initial data of mercury are not normally distributed and not stationary as well as many outliers so that the logarithmic transformation was needed on the initial data. After being transformed, the data shows a relatively normal and stationary distribution. ESDA aims to determine the relationship and spatial distribution of mercury values and determine treatment for outliers. ESDA results show that the sample was taken randomly and consist of one population. Before estimating with ordinary kriging, a semivariogram was made to determine the maximum distance of data that is still spatially related. Making a semivariogram has done with several experiments so that the most ideal semivariogram model was obtained. Estimation by ordinary kriging
\end{abstract}


shows that the anomaly zone of mercury has the trend that associated with NW-SE oriented faults in the west and east, and in the south that NE-SW oriented. The estimated Hg (log ppb) ranges from 1,869-1,989. Keywords: mercury; anomaly zone; ordinary kriging; Pamancalan

\section{PENDAHULUAN}

Panas bumi adalah salah satu sumber daya alam yang dapat dimanfaatkan dalam memenuhi kebutuhan energi listrik di Indonesia. Eksplorasi panas bumi dapat dilakukan dengan menganalisis data geokimia, salah satunya dengan menganalisis unsur Hg. Daerah penelitian pada studi ini adalah lapangan penelitian panas bumi Pamancalan, Kabupaten Lebak, Provinsi Banten.

Analisis data $\mathrm{Hg}$ menjadi sangat penting pada kegiatan eksplorasi panas bumi karena data yang diperoleh dari sampling dapat membantu dalam menentukkan target pengeboran, memperkirakan batas reservoir, dan secara umum dapat melihat daerah anomali (Suryantini, 2019a). Penelitian tentang persebaran nilai $\mathrm{Hg}$ di daerah Pamancalan sebelumnya telah diestimasi oleh Pusat Sumber Daya Geologi (PSDG) Jawa Barat. Akan tetapi, tidak dicantumkan metode yang digunakan dalam estimasi tersebut. Hal ini menyebabkan tidak diketahui nilai error yang ada pada metode estimasi

\section{Latar Belakang}

tersebut. Oleh karena itu penulis memutuskan untuk melakukan estimasi persebaran dari unsur $\mathrm{Hg}$ di lapangan panas bumi Pamancalan dengan menggunakan metode ordinary kriging.

Kriging adalah salah satu metoda interpolasi yang memanfaatkan nilai data serta hubungan spasial antar data-nya dalam menentukan bobot interpolasi berdasarkan model variogram(Suryantini, 2019b). Ordinary kriging adalah metode kriging paling sederhana yang terdapat pada geostatistika. Metode ini memiliki asumsi bahwa rata-rata (mean) tidak diketahui dan bernilai konstan (Haining, 1988; Cressie, 1991). Dengan stasioneritas orde dua lokal, ordinary kriging bisa secara implisit mengevaluasi rata-rata di lingkungan yang bergerak (Wackernagel, 1995). Tujuan penelitian ini adalah untuk mengestimasi nilai dari persebaran unsur $\mathrm{Hg}$ dan menganalisis ulang pola distribusi $\mathrm{Hg}$ serta memperkirakan daerah anomalinya dengan menggunakan metode ordinary kriging.

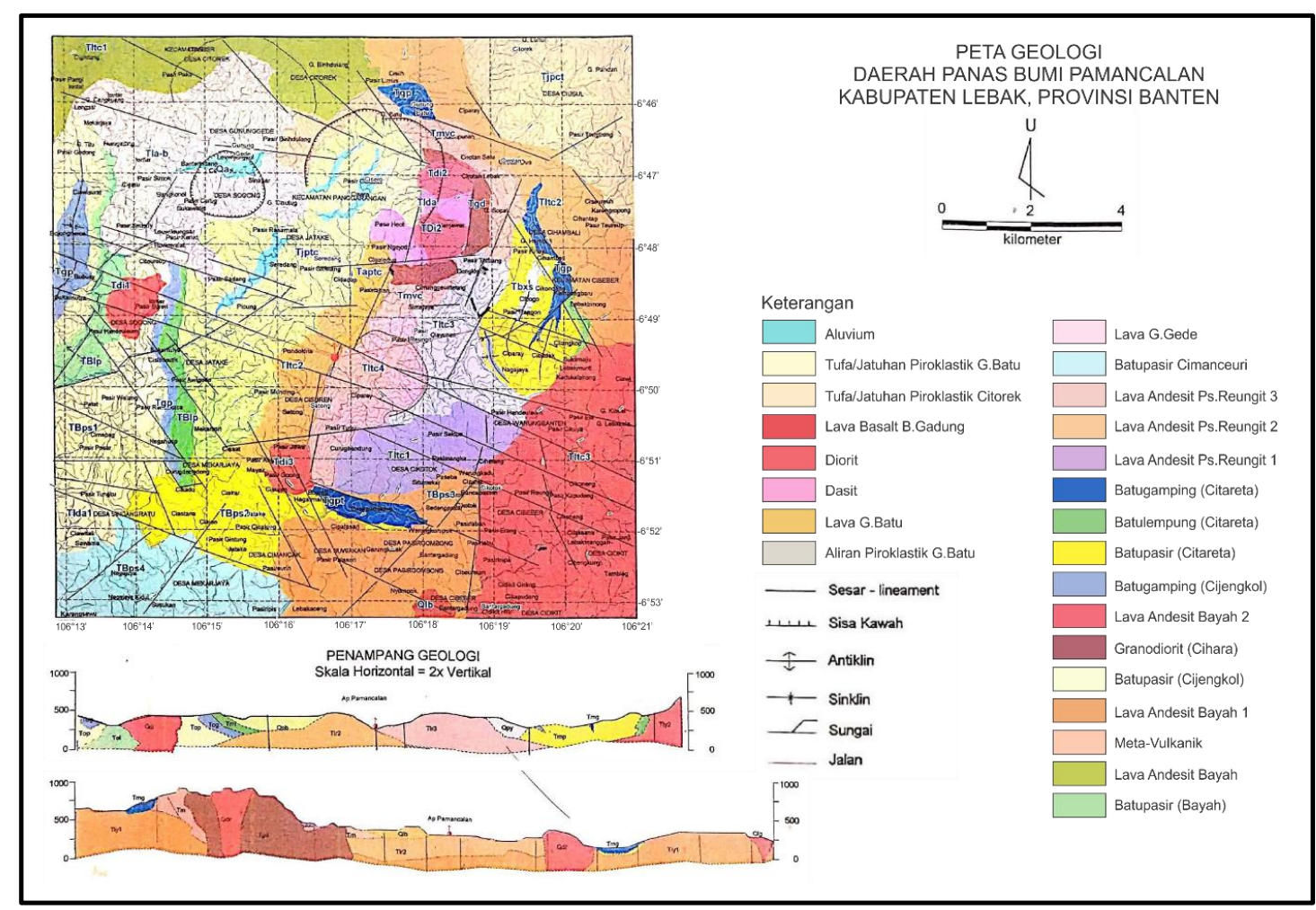

Gambar 1. Peta geologi daerah Pamancalan (Sumber: PSDG, 2011) 


\section{Geologi Regional}

Lapangan panas bumi daerah Pamancalan terletak di Kabupaten Lebak, Provinsi Banten. Daerah ini berada pada zona UTM 48S. Posisi daerah Pamancalan dalam tatanan tektoniknya termasuk dalam jalur magmatik Jawa bagian selatan dengan lingkungan vulkanik Litologi yang berada pada daerah penelitian adalah batugamping, batupasir, batulempung, breksi gunung api, dan tuf. Daerah panas bumi Pamancalan memiliki jumlah struktur geologi yang cukup banyak. Struktur geologi yang berkembang pada daerah penelitian ini adalah sesar. Secara umum sesar yang berada pada daerah penelitian memiliki orientasi NW-SE pada bagian barat dan timur dan beberapa berorientasi NE-SW pada bagian selatan daerah penelitian. Berdasarkan data geologi regional, perkembangan tektonisme di daerah kubah bayah dipengaruhi arah tegasan barat daya-timur laut atau arah subduksi Jawa-Meratus pada akhir Kapur. Kemudian dipotong oleh tegasan berarah utara atau pola Sunda pada Eosen Tengah. Sampai pola tegasan terakhir yang berlangsung hingga saat ini adalah pola Jawa yang berarah barat-timur (PSDG, 2011).

\section{METODOLOGI}

Data yang digunakan berupa 136 data sekunder persebaran unsur $\mathrm{Hg}$ yang bersumber dari hasil penelitian Pusat Sumber Daya Geologi (PSDG) pada lapangan panas bumi Pamancalan, Lebak, Banten. Penelitian ini menggunakan metode-metode geostatistik dengan asumsi bahwa data terdistribusi normal dan stasioner. Penelitian ini dimulai dengan analisis konsentrasi unsur $\mathrm{Hg}$ secara univariat berupa EDA (Exploratory Data Analysis). EDA dilakukan dengan membuat histogram, rangkuman statistik dan boxplot menggunakan aplikasi Microsoft Excel 2016. Dengan melihat rangkuman statistik, bisa dilihat apakah data terdistribusi normal atau tidak. Data yang unimodal dan hampir simetri dapat dengan mudah dianalisis lebih lanjut karena nilai mean, median, dan modus terletak pada satu nilai yang sama dan nilai mean $m$ serta standar deviasi ( $\sigma$ ) terletak di di tengah (Kitanidis, 1997). Nilai skewness dan kurtosis yang tinggi juga menunjukkan data yang tidak terdistribusi normal. Ketidaknormalan data tersebut bisa dilihat dari geometri histogram yang cenderung tidak simetris. Kriteria data terdistribusi normal adalah jika nilai skewnessnya 0-0,5 dan nilai kurtosisnya kecil dari 3. Jika nilai skewness 0,5-1 maka perlu dilakukan transformasi data dengan menggunakan akar kuadrat. Sedangkan jika nilai skewness $>1$, perlu dilakukan transformasi data dengan menggunakan logaritma. Boxplot berguna untuk melihat ada atau tidaknya outlier pada data. Jika terdapat outlier, maka diperukan penanganan (treatment). Outlier adalah nilai yang berada di luar dari kumpulan data pada box plot (Kitanidis, 1997).

Untuk menentukan penanganan terhadap outlier, perlu dilakukan ESDA (Exploratory Spatial Data Analysis) dengan menggunakan peta simbol (symbol map). Peta simbol dibuat untuk mengetahui hubungan outlier dengan data yang lain secara spasial. Jika outlier masih berhubungan dengan data lain (masih dalam satu populasi), maka outlier tersebut dapat dengan memasukkannya ke dalam kelas paling tinggi pada histogram. Apabila outlier tersebut terletak jauh dari data-data yang lain maka outlier tersebut dapat dihapus. Setelah didapatkan data terdistribusi normal dan stasioner, dilakukan pembuatan semivariogram eksperimental sebanyak enam kali untuk menemukan semivariogram dengan hubungan spasial yang paling baik. Percobaan tersebut dilakukan dengan mengubah lag distance.

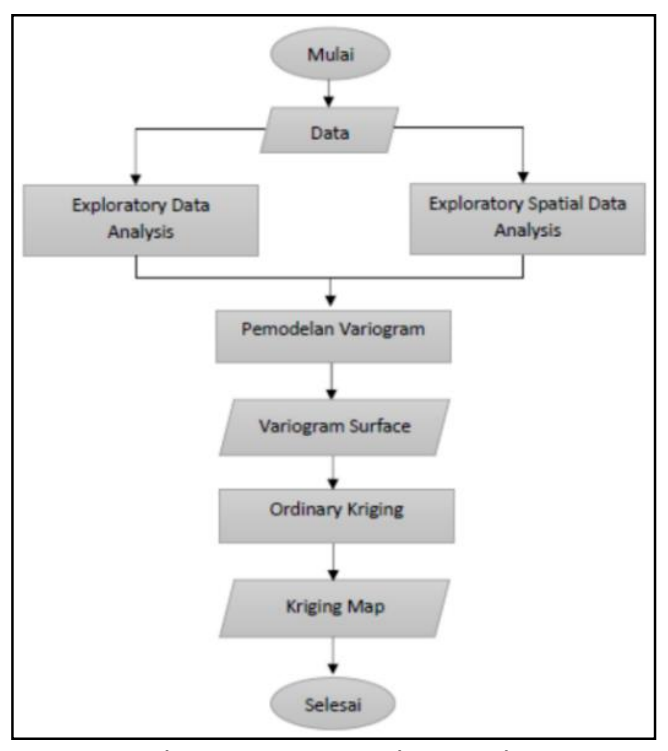

Gambar 2. Diagram alir penelitian

Selanjutnya dilakukan pemodelan semivariogram yang menghasilkan nilai range, sill, dan nugget tertentu. Dalam pemilihan model semivariogram dipilih model yang paling sesuai dengan residual kecil (Kitanidis, 1997). Tahap selanjutnya adalah membuat variogram surface untuk mengecek apakah data tersebut isotropi atau anisotropi. Jika data tersebut isotropi maka dapat 
dilanjutkan dengan ordinary kriging (Kitanidis, 1997). Dengan menggunakan aplikasi ILWIS 3.3 Academic. Hasil kriging kemudian akan olah dengan QGIS 2.18 untuk pembuatan peta distribusi $\mathrm{Hg}$. Gambar 2 menunjukkan diagram alir penelitian.

\section{HASIL DAN PEMBAHASAN}

\section{Exploratory Data Analysis (EDA) Unsur Hg}

Analisis EDA dilakukan untuk mengetahui karakteristik data $\mathrm{Hg}$ seperti rata-rata, modus, median dan standar deviasi. Data kelimpahan unsur $\mathrm{Hg}$ pada lapangan panas bumi Pamancalan berjumlah 136 dengan rentang 9-345 ppb. Data tersebut sudah cukup representatif untuk dilakukan analisis geostatistik. Berdasarkan ringkasan statistik yang dihasilkan dari analisis univariat, data memiliki nilai rata-rata 69,21; median 56,50; modus 61 ; dan standar deviasi 51,81. Rangkuman statistik data $\mathrm{Hg}$ disajikan Pada Tabel 1.

Nilai rata-rata, median, dan modus tidak memiliki nilai yang relatif sama serta nilai standar deviasi memiliki nilai yang relatif besar. Oleh karena itu disimpulkan bahwa data $\mathrm{Hg}$ ini tidak terdistribusi normal. Persebaran data $\mathrm{Hg}$ dapat dilihat pada Gambar 3.

Dari histogram terlihat bahwa data tidak simetris karena data terakumulasi di bagian kiri. Ketidaksimetrisan ini berhubungan dengan nilai skewness dan kurtosis data $\mathrm{Hg}$ yang tinggi. Dilihat dari tampilan boxplot data $\mathrm{Hg}$, persebaran data tidak terdistribusi dengan normal dan memiliki banyak outlier. Boxplot data $\mathrm{Hg}$ disajikan pada Gambar 4.

Tabel 1. Rangkuman statistik data $\mathrm{Hg}$

\begin{tabular}{|lr|}
\hline \multicolumn{2}{|c|}{ Data Hg } \\
\hline Mean & 69.21 \\
\hline Standard Error & 4.44 \\
\hline Median & 56.50 \\
\hline Mode & 61.00 \\
\hline Standard Deviation & 51.81 \\
\hline Sample Variance & 2683.78 \\
\hline Kurtosis & 7.24 \\
\hline Skewness & 2.24 \\
\hline Range & 336.00 \\
\hline Minimum & 9.00 \\
\hline Maximum & 345.00 \\
\hline Sum & 9412.00 \\
\hline Count & 136.00 \\
\hline
\end{tabular}

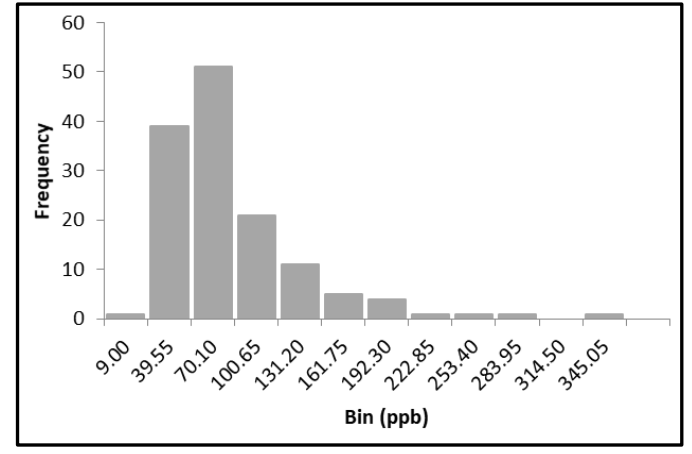

Gambar 3. Histogram data $\mathrm{Hg}$

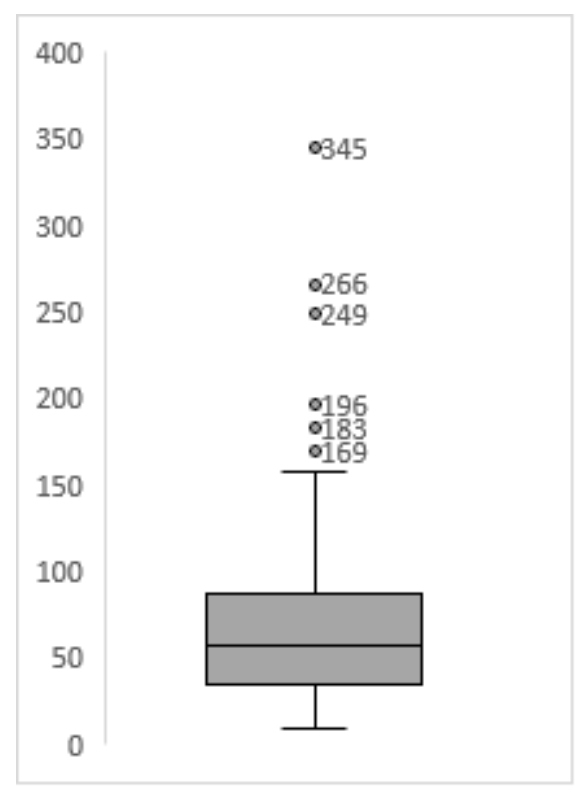

Gambar 4. Boxplot data $\mathrm{Hg}$

Agar pengolahan data dapat dilakukan secara spasial, data harus terdistribusi normal. Metode transformasi yang umum digunakan adalah transformasi logaritma agar data terdistribusi normal dan stasioner (Tukey, 1977). Rangkuman statistik data log $\mathrm{Hg}$ dapat dilihat pada Tabel 2.

Tabel 2. Rangkuman data log $\mathrm{Hg}$

\begin{tabular}{|lr|}
\hline \multicolumn{2}{|c|}{ Data Log Hg } \\
\hline Mean & 1.74 \\
\hline Standard Error & 0.03 \\
\hline Median & 1.76 \\
\hline Mode & 1.79 \\
\hline Standard Deviation & 0.30 \\
\hline Sample Variance & 0.09 \\
\hline Kurtosis & 0.11 \\
\hline Skewness & -0.10 \\
\hline Range & 1.59 \\
\hline Minimum & 0.95 \\
\hline Maximum & 2.54 \\
\hline Sum & 236.74 \\
\hline Count & 136.00 \\
\hline
\end{tabular}




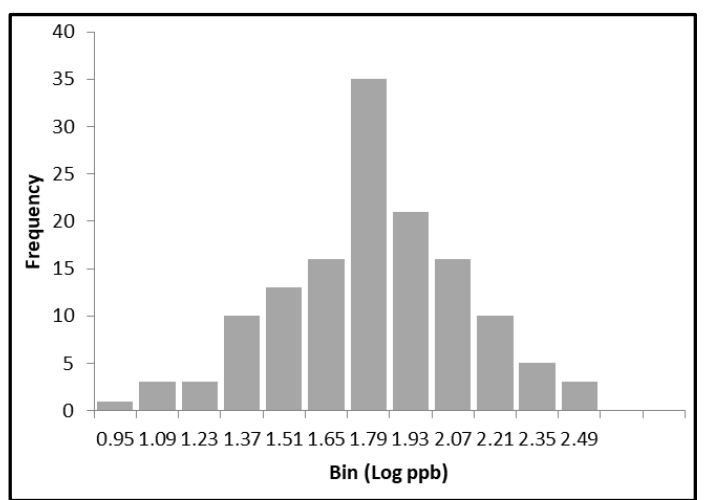

Gambar 5. Histogram data log $\mathrm{Hg}$

Setelah dilakukan transformasi logaritma data log $\mathrm{Hg}$ memiliki nilai rata-rata 1,74; median 1,76; dan modus 1,79 . Nilai rata-rata, median, dan modus memiliki perbedaan yang kecil sehingga dapat diasumsikan data tersebut terdistribusi normal. Pada data log $\mathrm{Hg}$ nilai standar deviasi lebih kecil dibandingkan dengan nilai rata-rata nya. Hal tersebut menunjukkan data telah relatif stasioner. Persebaran data log $\mathrm{Hg}$ dapat dilihat pada Gambar 5. Histogram data log $\mathrm{Hg}$ menunjukkan skewness yang cenderung negatif yang didominasi dengan data log $\mathrm{Hg}$ yang memiliki nilai relatif besar. Pada boxplot data log $\mathrm{Hg}$, persebaran data relatif lebih normal dan memiliki outlier yang lebih sedikit dibandingkan dengan data $\mathrm{Hg}$. Sehingga data log $\mathrm{Hg}$ dapat diolah lebih lanjut dengan membuat semivariogram. Pada Gambar 6 disajikan boxplot data log $\mathrm{Hg}$.

Pada Gambar 6 terlihat masih terdapat dua buah outlier. Dalam menentukan treatment apa yang akan dilakukan terhadap outlier tersebut, perlu dilakukan ESDA (Exploratory Spatial Data Analisis) untuk melihat susunan data secara spasial (spatial arrangement).

\section{Exploratory Spatial Data Analysis (ESDA) Unsur Hg}

Dari pengolahan data dengan EDA didapatkan outlier didapatkan dua buah outlier yaitu 2,54 dan 0,95 . Untuk menentukan jenis penanganan (treatment) yang akan diberikan kepada outlier, maka perlu dilakukan pengeplotan distribusi spasial data. Distribusi spasial data perlu diperhatikan untuk menghindari bias dan melihat hubungan nilai antar lokasi sampel. Hal ini dikarenakan metode geostatistik didasarkan pada ketergantungan nilai (spatial dependency) dan susunan data secara spasial (spatial arrangement). Gambar 20 menunjukkan peta simbol data log $\mathrm{Hg}$. Dari peta simbol tersebut dapat dilihat bahwa sampling

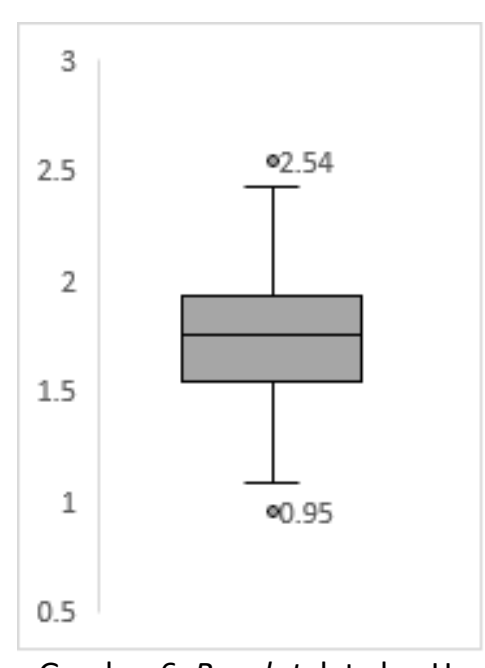

Gambar 6. Boxplot data log $\mathrm{Hg}$

dilakukan secara acak. Dalam peta simbol terlihat kedua outlier masih berhubungan secara spasial dengan data yang lain. Oleh karena itu, outlier yang bernilai 0,95 dan 2,54 tetap dimasukkan untuk analisis selanjutnya.

\section{Semivariogram}

Untuk mengetahui nilai log $\mathrm{Hg}$ pada titik yang tidak disampel, dilakukan interpolasi menggunakan metode ordinary kriging. Sebelum melakukan estimasi kriging, dilakukan pembuatan model semivariogram. untuk memperlihatkan hubungan antara variansi (semivariogram) dengan jarak antara data (lag distance). Pembuatan model semivariogram bergantung pada data dan keadaan geologi di daerah penelitian. Langkah pertama pada pembuatan model adalah dengan mengeplot data. Selanjutnya, pemodelan dilakukan untuk menentukkan komponen variogram paling baik dengan error terkecil dapat menggunakan metode IRF.

Intrinsic Random Function (IRF) adalah fungsi acak yang kenaikannya adalah stasioner pada orde kedua. Ini ditandai dengan pergeseran liniernya (Chilès dan Delfiner, 1999).

$$
\gamma(h)=\frac{1}{2} \operatorname{Var}[Z(x)-Z(x+h)]
$$

dengan:

h : notasi untuk menandakan antara titik sampel

$\mathrm{Z}(\mathrm{x})$ : nilai yang diobservasi untuk satu parameter pada jarak $x$

$\mathrm{Z}(\mathrm{x}+\mathrm{h})$ : nilai untuk satu parameter pada jarak $\mathrm{x}+\mathrm{h}$ Dalam pembuatan semivariogram eksperimental dipilih model yang paling sesuai yaitu spherical omnidirectional dan dilakukan sebanyak delapan kali percobaan. Dengan menggunakan 
aplikasi ILWIS 3.3 Academic, dibuat semivariogram dengan lag 250m, 500m, 750m, 1000m, 1250m, $1500 \mathrm{~m}, 1750 \mathrm{~m}$ dan $2000 \mathrm{~m}$. Setelah didapatkan lag dengan nilai nugget, sill, dan range yang sesuai, dilakukan pembuatan variogram surface untuk menentukan apakah data tersebut isotropi atau anisotropi. Hal ini akan menentukan jenis estimasi dari metode kriging yang akan digunakan.

\section{Lag 250m}

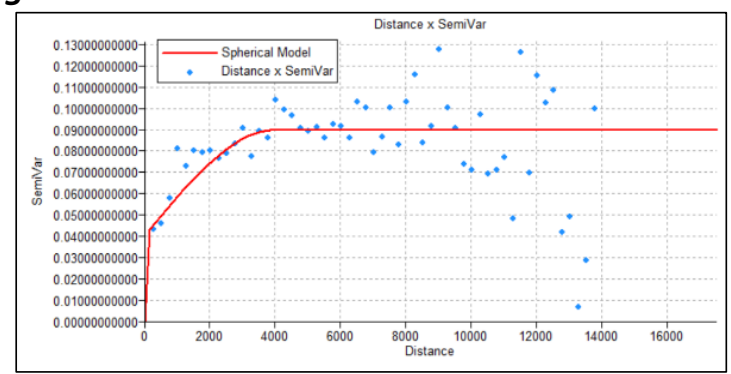

Gambar 7. Grafik variogram lag 250m

\section{Lag 500m}

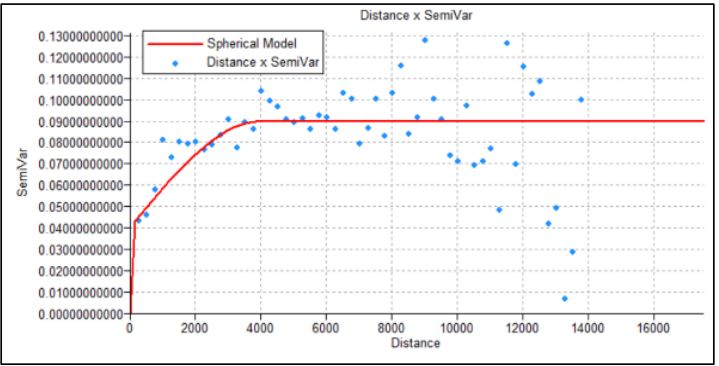

Gambar 8. Grafik variogram lag 500m

\section{Lag 750m}

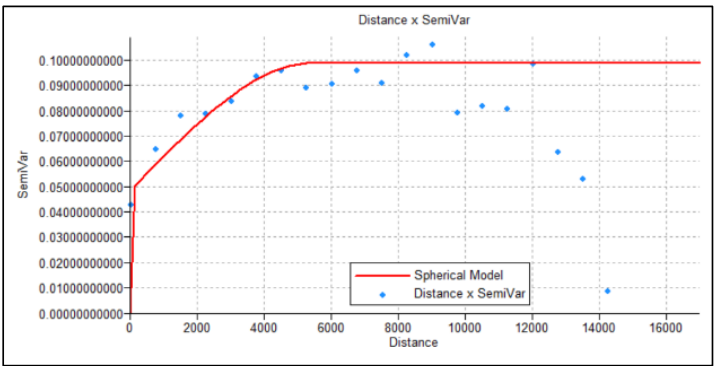

Gambar 9. Grafik variogram lag 750m

\section{$\operatorname{Lag} 1000 \mathrm{~m}$}

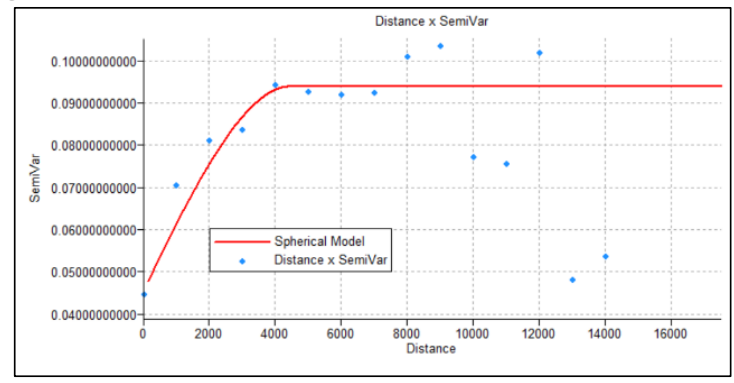

Gambar 10. Grafik variogram lag 1000m

\section{$\operatorname{Lag} 1250 \mathrm{~m}$}

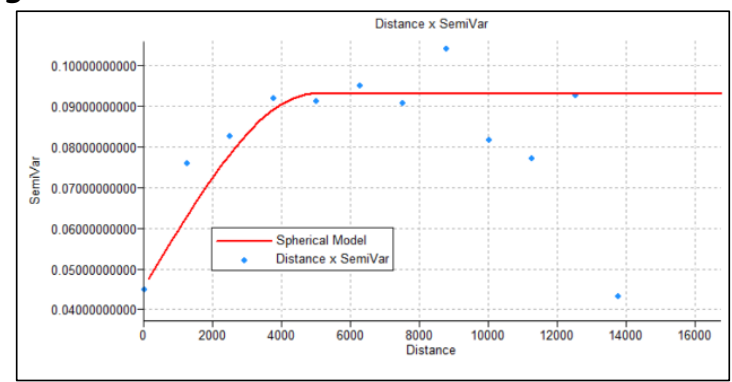

Gambar 11. Grafik variogram lag 1250m

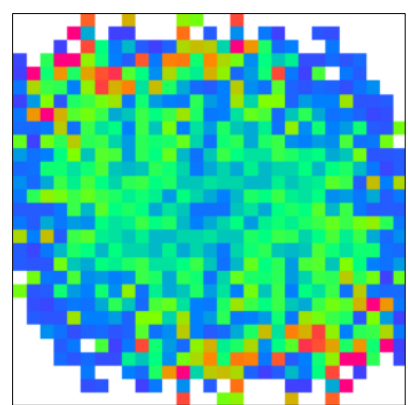

Gambar 12. Variogram Surface lag $750 \mathrm{~m}$

\section{Lag 1500m}

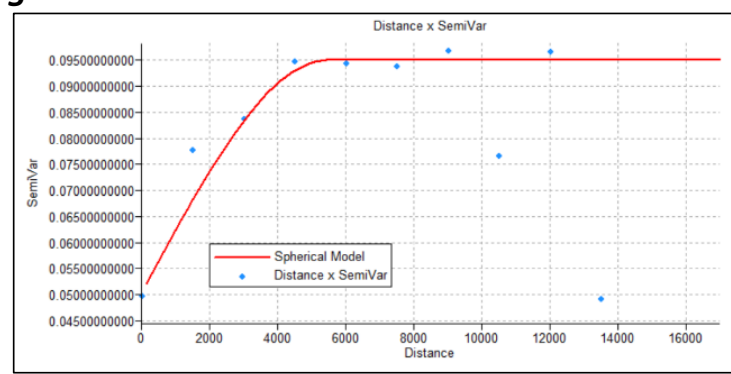

Gambar 13. Grafik variogram lag 1500m

\section{Lag 1750m}

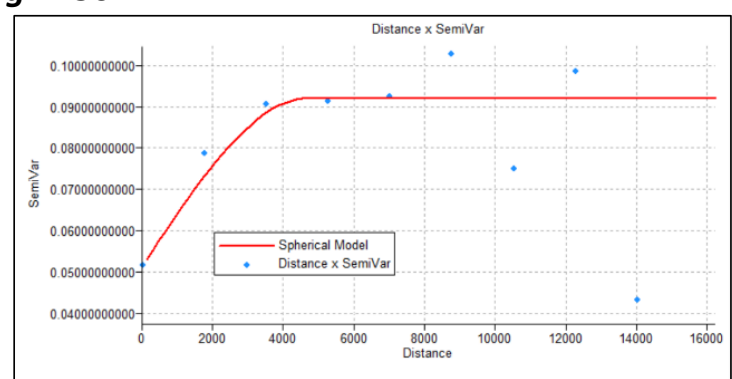

Gambar 14. Grafik variogram lag 1750m

Lag 2000m

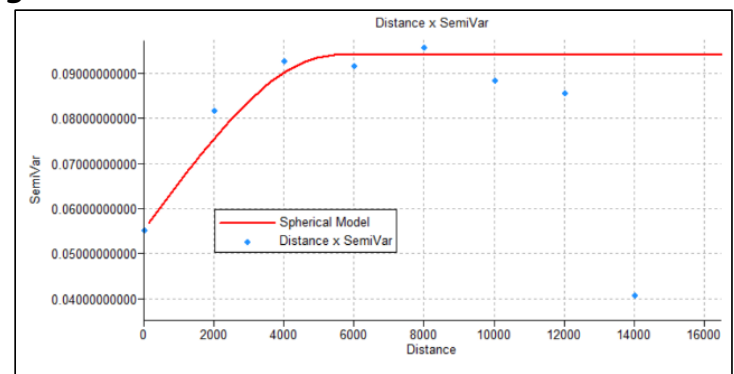

Gambar 15. Grafik variogram lag 2000m 
Dari percobaan menentukan lag semivariogram diatas, dipilih semivariogram yang paling sesuai dan memiliki error yang paling kecil yaitu semivariogram dengan lag distance sebesar $750 \mathrm{~m}$. Semivariogram tersebut memiliki nilai nugget $=0,048$; sill $=0,099$; dan range $5550 \mathrm{~m}$. Model dari semivariogram dengan lag 750m dapat dilihat pada Gambar 9.

Setelah didapatkan lag dari semivariogram, kemudian dilakukan pembuatan variogram surface dengan lag sebesar 750m untuk mengecek apakah pemodelan data semivariogram tersebut merupakan isotropi atau anisotropi. Hasil dari variogram surface dapat dilihat pada Gambar 12. Dari hasil variogram surface, dapat diketahui bahwa data tersebut memiliki trend dengan arah N-S, E-W, NW-SE dan NE-SW relatif sama. Sehingga dapat disimpulkan bahwa pemodelan data tersebut relatif isotropi.

Tabel 3 Kesimpulan Variogram

\begin{tabular}{|ccccc|}
\hline Lag $(m)$ & Nugget $\left(C_{0}\right)$ & Sill $\left(C_{0}+C\right)$ & Range $(m)$ & $\left(C_{0}\right) /\left(C_{0}+C\right)$ \\
\hline 250 & 0.040 & 0.090 & 4000 & 0.44 \\
\hline 500 & 0.032 & 0.090 & 4000 & 0.36 \\
\hline 750 & 0.048 & 0.099 & 5500 & 0.48 \\
\hline 1000 & 0.045 & 0.094 & 4500 & 0.48 \\
\hline 1250 & 0.045 & 0.093 & 5000 & 0.48 \\
\hline 1500 & 0.050 & 0.095 & 5500 & 0.53 \\
\hline 1750 & 0.051 & 0.092 & 4700 & 0.55 \\
\hline 2000 & 0.055 & 0.094 & 4800 & 0.58 \\
\hline
\end{tabular}

Kriging

Parameter yang digunakan pada kriging ditentukan secara statistik berdasarkan model semivariogram yang telah dipilih. Karena pemodelan data tersebut merupakan isotropi maka dapat dilakukan estimasi persebaran unsur data log $\mathrm{Hg}$ dengan interpolasi menggunakan metode ordinary kriging. Hasil kriging log $\mathrm{Hg}$ menggunakan aplikasi ILWIS 3.3 Academic pada daerah penelitian disajikan pada gambar 16 dan peta error kriging data log $\mathrm{Hg}$ pada gambar 17.

Pada peta kriging log $\mathrm{Hg}$, nilai estimasi berkorelasi dengan hasil pengambilan sampel. Konsistensi dari suatu metode interpolasi kriging dapat diuji dengan melakukan pengujian validasi hasil kriging dengan menghilangkan data sebanyak 5 buah secara acak pada data unsur log Hg. Data tersebut kemudian diinterpolasi kembali dengan nilai nugget, sill, dan range yang sama pada interpolasi sebelum melakukan validasi. Hal ini dilakukan untuk mengecek apakah data tersebut masih menunjukkan hasil yang sama untuk data yang dihilangkan. Pada pengujian validasi data yang dilakukan, didapatkan trend dari model validasi yang sama dengan trend dari peta estimasi kriging persebaran data log $\mathrm{Hg}$ sebelum 5 data dihilangkan. Oleh karena itu, dapat disimpulkan bahwa model interpolasi dengan ordinary kriging yang telah dibuat merupakan model yang sesuai dan konsisten dalam pemodelan persebaran data log $\mathrm{Hg}$ di wilayah panas bumi Pamancalan. Nilai error kriging yang didominasi oleh warna biru (berkisar antara 0,2409$0,3289)$ tergolong kecil jika dibandingkan data yang berkisar antara 0,95-2,5.

\section{Interpretasi}

Unsur Hg merupakan unsur volatil yang umum di-sampling dalam eksplorasi panas bumi. Akibat adanya panas pada bawah permukaan, unsur $\mathrm{Hg}$ akan menguap dan terakumulasi pada lapisan tanah. Daerah dengan kadar $\mathrm{Hg}$ yang tinggi merupakan daerah yang memiliki permeabilitas tinggi dan berasosiasi dengan struktur geologi, khususnya pada penelitian ini adalah sesar.

Dari hasil estimasi nilai unsur log $\mathrm{Hg}$ pada lapangan panas bumi daerah Pamancalan dengan menggunakan metode ordinary kriging, didapatkan hasil nilai persebaran $\mathrm{Hg}$ yang tinggi pada daerah di bagian tenggara lapangan panas bumi Pamancalan. Nilai persebaran $\mathrm{Hg}$ yang tinggi juga memiliki trend berarah NW-SE pada bagian barat dan timur daerah penelitian berkorelasi dengan struktur geologi berupa sesar yang berorientasi NW-SE. Pada bagian selatan daerah penelitian terdapat beberapa sesar berorientasi NE-SW yang kemungkinan juga berkorelasi dengan anomali unsur $\mathrm{Hg}$. Daerah yang memiliki nilai unsur $\mathrm{Hg}$ rendah terdapat di bagian tengah daerah penelitian dengan orientasi utaraselatan.

\section{PENUTUP}

Persebaran data log $\mathrm{Hg}$ dengan menggunakan metode ordinary kriging memiliki trend anomali yang berasosisasi dengan sesar yang memiliki orientasi NW-SE pada bagian barat dan timur, serta pada daerah selatan yang berorientasi NE-SW. Sedangkan hasil estimasi persebaran unsur $\mathrm{Hg}$ yang dilakukan oleh Badan Pusat Sumber Daya Geologi (PSDG), anomali hanya terkumpul pada satu titik atau disebut 'bull's eye' dan tidak terdapat trend. Berdasarkan hal tersebut dapat disimpulkan bahwa hasil estimasi persebaran data log $\mathrm{Hg}$ dengan menggunakan metode geostatistik yaitu ordinary 
kriging didapatkan hasil yang lebih akurat karena memiliki nilai error dari hasil estimasi dibandingkan dengan estimasi persebaran Hg oleh PSDG Jawa Barat karena tidak mencantumkan metode sehingga nilai error dari hasil estimasi tidak dapat diketahui.

Penulis menyadari bahwa paper ini masih jauh dari kata sempurna. Oleh karena itu, saran dan kritik yang membangun dari rekan-rekan sangat kami butuhkan untuk memperbaiki paper ini.

\section{Ucapan Terima Kasih}

Terimakasih kepada Tim Survei Terpadu dari Pusat Sumber Daya Geologi (PSDG) Bandung yang telah mengizinkan kami menggunakan data PSDG untuk penelitian ini. Penulis tentunya juga berterima kasih atas bimbingan Ibu Dr. Eng. Suryantini, M.Sc. dan Bapak Hendro Wibowo, M.Sc. dalam pembuatan paper ini serta teman-teman dari HMTG "GEA" ITB yang telah memberikan semangat kepada penulis sehingga penelitian ini dapat diselesaikan.

\section{DAFTAR PUSTAKA}

Chilès, J.-P. dan Delfiner, P. (1999), Geostatistics: Modeling Spatial Uncertainty, John Wiley and Sons, Inc, New York.

Cressie, N.A.C. (1991), Google-Books-ID: k_JQAAAAMAAJ, Statistics for Spatial Data, John Wiley and Sons, Inc, New York.

Kitanidis, P.K. (1997), Google-Books-ID: ZvoibTTS9QwC, Introduction to Geostatistics: Applications in Hydrogeology, Cambridge University Press, Cambridge.

PSDG (2011), Survei Panas Bumi Terpadu Geologi dan Geokimia Daerah Panas Bumi Pamancalan, Kabupaten Lebak, Provinsi Banten, Kementrian Energi dan Sumber Daya Mineral, Badan Geologi, Pusat Sumber Daya Geologi, Bandung.

Suryantini (2019a), Geostatistik : Tutorial Kriging (ILWIS), Institut Teknologi Bandung, Bandung.

Suryantini (2019b), Geostatistik: Tutorial Variogram (ILWIS), Institut Teknologi Bandung, Bandung.

Tukey, J.W. (1977), Exploratory Data Analysis, 1 edition., Addison-Wesley, Massachusetts.

Wackernagel, H. (1995), Multivariate Geostatistics: An Introduction with Applications, Springer-Verlag Berlin Heidelberg, New York. http://doi.org/10.1007/978-3-662-05294-5. 